\title{
Male Teachers as Role Models: Addressing Issues of Masculinity, Pedagogy and the Re-Masculinization of Schooling
}

\author{
WAYNE JOHN MARTINO \\ The University of Western Ontario \\ London, Ontario, Canada
}

\begin{abstract}
This article focuses on the call for more male teachers as role models in elementary schools and treats it as a manifestation of "recuperative masculinity politics" (Lingard \& Douglas, 1999). Attention is drawn to the problematic gap between neo-liberal educational policy-related discussions about male teacher shortage in elementary schools and research-based literature which provides a more nuanced analysis of the impact of gender relations on male teachers' lives and developing professional identities. In this sense, the article achieves three objectives: (1) it provides a context and historical overview of the emergence and re-emergence of the male role model rhetoric as a necessary basis for understanding the politics of "doing women's work" and the anxieties about the status of masculinity that this incites for male elementary school teachers; (2) it contributes to existing literature which traces the manifestation of these anxieties in current concerns expressed in the popular media about the dearth of male teachers; (3) it provides a focus on research-based literature to highlight the political significance of denying knowledge about the role that homophobia, compulsory heterosexuality and hegemonic masculinity play in "doing women's work." Thus the article provides a much-needed interrogation of the failure of educational policy and policy-related discourse to address the significance of male teachers "doing women's work" through employing an analytic framework that refutes discourses about the supposed detrimental influences of the feminization of elementary schooling.
\end{abstract}

\section{INTRODUCTION}

Putting a man, any man, in place of women in school will not do. A man who is less than a man can be more damaging to boys than domineering mothers. (Sexton, 1969, pp. 29-30)

This article raises important questions about the politicized function of the male role model discourse within the context of "moral panic" which has intensified in recent times in response to the declining number of male

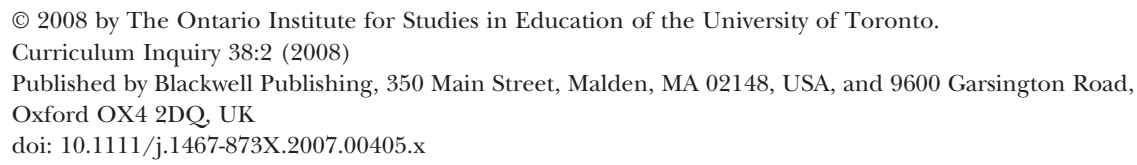


teachers in elementary schools (see Acker, 1995/1996; Elementary Teachers' Federation of Ontario, 2003; NEA, 2004; Skelton, 2002, 2003). This is often expressed in the popular media and educational forums through discourses which construct male teachers as a "dying breed" and, hence, facing "extinction" (Cloer, 2006; Elementary Teachers' Federation of Ontario, 2006; Mitchell, 2004; NEA, 2004). The intensification of such calls reflects a deep anxiety about the status of culturally acceptable versions of masculinity in the dominant culture which results in a failure to address the gender politics and dynamics of sexuality that are implicated in the devalued status attributed to doing "women's work" (Williams, 1993). As Smedley (2006) reveals, versions of normative heterosexual masculinity impact in significant ways on how male teachers are perceived and perceive themselves within the context of a female-dominated occupation (see Carrington, 2002; Francis \& Skelton, 2001; Skelton, 2001, 2002, 2003; Williams, 1993).

It is important to note that male teachers as a minority in elementary schools is not a new phenomenon. Concerns about feminization and its potential to contaminate men's and boys' masculinity-and to raise questions about their sexuality-have intensified at certain historical junctures since the mid-1800s (see Acker, 1995/96; Blount, 2005). ${ }^{1}$ Against such a historical backdrop, I argue that current calls for more male teachers as role models need to be understood as part of a broader cultural project of re-masculinization, which is manifested in terms of a backlash against the perceived threat posed by women who have begun to make some "headway toward equality" (Faludi, 1991, p. 46). While male teachers have always been a minority in elementary schools, I argue that the intensification of current calls for more male role models represents another instance historically of the recurring phenomenon of backlash (see Lingard \& Douglas, 1999, who provide evidence of this broader project of re-masculinization; Martino \& Berrill, 2003; Mills, Martino, \& Lingard, 2004). This is reflected more broadly in the culture where fears of emasculation continue to be signified through what has been termed in North America as "the age of the wuss" or "the sorry state of manhood" (Gilles, 2005), resulting in the "pussification of the western male" (du Toit, 2003).

Thus, what is avoided in policy-related and populist discourses invoking male role models, I propose in this article, is the necessity of placing under critical investigation the effects of a regime or culture of hegemonic masculinity and gender normalization which produces the very polemic that contributes to the decline of male teachers entering elementary schools in the first place. In addition, it is such gender normalization which incites anxieties about feminized and/or emasculated boys in schools and contributes to the differential status accorded to work requiring capacities designated as "feminine" (see King, 1998; Williams, 1993). Hence, the capacity to examine the potential for investigating the impact of hegemonic masculinity on male teachers' pedagogical practices and relations 
with students in classrooms is lost or more aptly denied. In fact, within the context of the limits imposed by a neo-liberal framework of moral concern about the dearth of male elementary teachers in schools, the latter are positioned often as victims or a "dying breed" in need of affirmative action or equal opportunity intervention (see Ontario College of Teachers, 2004; see also Carrington, 2002; Martino \& Berrill, 2003; Martino \& Kehler, 2006; Mills et al., 2004; Pepperell \& Smedley, 1998 for a critique of such approaches). In short, rather than providing a more nuanced analysis of the impact of gender relations on male teachers' lives and professional identities, which link the micro or localized dimensions of their everyday experiences and negotiation of masculinities in school communities with a broader macro and historical analysis about the status of elementary teaching as "women's work, a familiar rhetoric is deployed in policy-related discussions about the need for more male role models that leaves unproblematized the construction of valorized hegemonic heterosexual masculinity (Carrington, 2002; Elementary Teachers' Federation of Ontario, 2003; Mills et al., 2004; Ontario College of Teachers, 2004; Skelton, 2001). In light of this polemic, the aim of this article is threefold:

(i) It draws on specific historical accounts of the feminization of teaching as a basis for understanding the emergence and re-emergence of the male role model rhetoric within the context of the status attributed to doing women's work. These historical accounts draw attention to the need for policy-related discourse to engage with broader socio-cultural, queer and feminist analytic frameworks for understanding the contradictory experiences of hegemonic masculinity in male teachers professional lives (Allan, 1994; Britzman, 1993, 1998; Foster \& Newman, 2005; Sargent, 2005; Skelton, 2002).

(ii) It foregrounds the cultural anxiety about masculinity that lies at the heart of moral concerns about the dearth of male teachers in the popular media in the North American context. This critical focus on masculinity, within the context of moral panic, provides the basis for examining how gender relations and sexuality mediate male teachers' pedagogical practices and relations with their students in ways that avoid positioning the former as victims of reversed sexism (see Lingard \& Douglas, 1999; Martino \& Kehler, 2006).

(iii) It provides a focus on selected literature in the field to mount a case for the need for educational policy concerned with male teacher shortage in elementary schools to address broader issues of the status of teaching as women's work (see Williams, 1993). This literature provides a basis for foregrounding the role that homophobia, compulsory heterosexuality and hegemonic masculinity play in determining both the limits of male teachers' professional identities and their pedagogical practices in classrooms (see 
Carrington, 2002; Coulter \& McNay, 1993; Foster \& Newman, 2005; Francis \& Skelton, 2001; Martino \& Frank, 2006; Sargent, 2005; Skelton, 2001, 2002, 2003; Smedley, 2006).

\section{POLICY CONTEXT AND ANALYTIC PERSPECTIVE}

My main proposition in this article is that the perceived intensified feminization of elementary schooling and the anxieties it incites for men doing women's work represents another example of defensive masculinity with educational policy and the public media responding in ways which present men as victims who are in need of affirmative action initiatives to increase their presence in a female-dominated world where boys are being deprived of suitable role models (Lingard \& Douglas, 1999; Mills et al., 2004). Mills, Martino, and Lingard (2007) provide a detailed critique of the Australian government's neo-liberal policy agenda vis-à-vis boys' education and the feminization of schooling which includes a focus on the male teacher as role model. This is also documented by Martino $(2004,2006)$ who undertakes both a media and policy analysis of the male teacher debate as it relates to boys' education in the Australian context. Mills et al. (2004) undertake a more specific analysis of Education Queensland policy initiative in Australia to recruit more male teachers which they frame as part of a broader project of re-masculinization. Furthermore, these policy-related critiques are consistent with those undertaken by Martino and Kehler (2006) and Martino (2008) in Ontario, Canada, as well as those elaborated by Carrington (2002), Pepperell and Smedley (1998), and Skelton (2002) in the United Kingdom.

Pepperell and Smedley (1998), for example, have argued that calls for more male role models in elementary schools "are often couched in dramatic terms and are being transformed into policy proposals" (p. 341). This is supported by Carrington (2002) who documents the extent to which policy makers in England and Wales continue to attribute the problem of boys' underachievement to the lack of male role models in elementary schools and in the home (p. 288). The problem is that any analysis of the gender politics at play for men doing women's work and the historical and economic legacy of the gendered division of labour is bleached from much of the media-generated and educational policy-related discussions pertaining to male teacher shortage (see Acker, 1995/96; Altenbaugh, 1992; Biklen, 1995; Miller, 1996). As Lawn and Grace (1987) argue, "although women constitute great majority of teachers in most societies, the significance of gender relations and women's experience of patriarchal structures and practices within the occupation have been scarcely commented upon" within the policy context (p. ix). In this sense, the male teacher debate needs to be considered in relation to the emergence of discourses about men and boys as the "new disadvantaged" through education policy formu- 
lation and the popular media, which fail to address the broader significance and salience of gender regimes, particularly as they relate to the organizational structure of labour relations in schools (see Acker 1995/96; Lingard \& Douglas, 1999; Martino \& Kehler, 2006). For example, Mahony, Hextall, and Menter (2004) emphasize that while "women teachers outnumber by 2:1 overall, yet men continue to be over-represented at headteacher level" (p. 134), indicating the gender politics at play in the career progression and promotion trajectories "in a profession where, relative to their numbers, men occupy a disproportionate number of headteacher posts" (p. 133; see also Acker, 1989, p. 199).

My focus in this article, therefore, is on examining how a particular politics of hegemonic masculinity informs apparent innocuous and justifiable claims about redressing a gender imbalance in the teaching profession vis-à-vis the under-representation of male teachers in elementary school classrooms (Connell, 1995; Frank, 1987). My main argument is that the rhetoric surrounding the call for male role models in elementary schools relies on certain common-sense assumptions and anxieties about the influence of feminization on boys' developing masculinities which are driven, often implicitly, by a limited understanding about the need for adequate sex role identification as a panacea for addressing the problems boys are experiencing in schools (see Martino, 2004, 2006; Martino \& Kehler, 2006). In short, being a role model becomes synonymous with being a "real man" who is able to ensure that boys' masculinity remains intact or is appropriately cultivated. Allan (1994) traces such discourses about sex-role identification to the 1960 s and 1970 s where deviant hypermasculinity and its corollary of effeminacy in boys and adult males were attributed to the absence of fathers and, hence, their importance in modeling "acceptable" masculinity for boys. However, Blount (2005) provides a history of teaching since the mid-19th century in the United States which documents the re-emergence of such anxieties about either the absence of "real men" or the questionable status of "effeminate men" in the provision of appropriate sex-role socialization for boys. The focus on such historical perspectives in this article is deliberate, given that they illuminate the heteronormative force of gender and sexuality in terms of its capacity to impact on the regulation and surveillance of teachers' lives and the conditions of their work in schools. Such perspectives, for the most part, are absent from policy-related discourses. In this sense, I argue that such knowledge can help to build a deeper understanding about "the impulse to normalize" that continues to govern current calls for more male role models in elementary schools (Britzman, 1993, 1998, p. 92). This is not to deny that the phenomenon of feminization of teaching has operated differently in different contexts and that it was influenced by "different groups of settlers, local economic conditions and rates of bureaucratization" (see Acker, 1995/96, p. 116; Barman, 1990; Danylewycz, Light, \& Prentice, 1983; Prentice \& Theobald, 1991). The aim of this article is merely to gesture 
towards how a historical analysis, which addresses the normative force of gender, as it impacts on both the status of elementary schooling and teacher identity, has the potential to shift the terms of the debate about male teacher shortage in elementary schools from a moral concern about the lack of role models to a consideration of the politics of gender and sexuality vis-à-vis the status of doing women's work.

In addition, by highlighting particular analytic perspectives such as those offered by Blount (2005) and Cavanagh (2006), attention is drawn to both the significance and need to employ analytical frameworks which foreground the interconnected relations of normative heterosexual masculinity, compulsory heterosexuality and heteronormativity, as they pertain to the various ways in which both male and female teachers' identities are policed and subjected to the normalizing and pathologizing gaze of experts and educational authorities. Britzman, for example, draws attention to the limits of sex role theories in that they assume a uniform set of expectations about men and women and, hence, fail to explain "the contradictory ways individual identities are rooted in larger histories and in social structures" (p. 35). In this sense, acquiring roles is often treated as passively adopting an identity and, thus, fails to attend to the complex and contradictory messiness of gender relations (see also Coulter \& McNay, 1993; Gold \& Reis, 1982). Moreover, as Britzman points out, sex role theory fails to address questions of sexuality and is also grounded in essentialism in that it fails to address the emotional investments that compel individuals to embrace particular normative identities and the conflict that can result as one attempts to live these roles.

Britzman also draws attention to the moral imperatives driving the call for role models, given that role models are often considered to be an antidote to addressing what is perceived to be a social ill or problem:

The point is that, although role models always model a particular version of morality, the way they are handled prevents any critical discussion of how morality becomes constituted. (p. 38)

These analytic insights are particularly pertinent, given the debates about the lack of male role models in elementary schools, which take on the tenor of moral panic and concern vis-à-vis the threat that female teachers pose in terms of their supposed capacity to emasculate boys (see Hoff Sommers, 2000; Titus, 2004). Underscoring such concerns are also fears about the sissification of boys and, hence, the heteronormative force of the call for more male teachers to save boys from the grips of gender deviancy. The point is that invoking such moral imperatives about male role models forecloses any critical discussion about the dynamics of gender and sexuality sustaining the heteronormative definitions of what constitutes a sex role model and, more specifically, what version of masculinity is being advocated. These discourses invoking male role models as the panacea, as 
I will illustrate, are tied to a project of re-masculinization, committed to an investment in maintaining stereotypical appearances and naturalizing heterosexuality by denying the contradictory effects of gender relations, that has a historical legacy. In this sense, the analytic perspective adopted in this article is situated within the broader field of gender and queer studies in terms of its potential to inform our understanding of the politics of gender and sexuality within the context of current debates about male role models and elementary schooling (Bland \& Doan, 1998; Cavanagh, 2006; Petersen, 1998; Sears, 1999; Talburt \& Steinberg, 2000).

\section{The Historical Legacy of Teaching as Women's Work}

The gender politics surrounding elementary teaching as women's workwith its emasculating associations for male teachers and boys-has a history that can be traced back to the mid-1800s. In fact by the early 19th century, teaching came to be constituted as an extension of the domestic duties deemed appropriate for women (see Altenbaugh, 1992; Biklen, 1995; Heap \& Prentice, 1991; Sugg, 1978). Thus teaching and its association with mothering and, hence, the nurturing of young children, needs to be understood historically within the economic and socio-cultural context of the sexual division of labour, which was (and continues to be) predicated on a devaluation of feminized work, relative to other masculinized professions (see Bhroimeil, 2006; Bradley, 1993; Coulter \& Harper, 2005; Heap \& Prentice, 1991; Prentice \& Theobald, 1991). Rury (1989), for example, links the feminization of teaching since the 1850s to changing labour markets at a time when "virtually every other profession in American life was dominated by men" (p. 10). The feminization of teaching, he claims, "helped to assure that teaching would not be recognized as a profession in the same terms, say, as law or medicine" (p. 10). Thus teaching emerged in the popular consciousness over time as "women's work." The feminization of teaching is both attributed to the sexual division of labour and to the intensification of a domestic ideology in response to the changing social and economic conditions affecting both men and women in increasingly industrialized societies: "In a society which was permeated with sexist conventions about success, the identification of teaching with women often meant that teachers were held in low esteem" (p. 10).

This is highlighted to a far greater degree when one considers the role that teaching played in many women's and men's life trajectories in the nineteenth century. At this time, it was a "pursuit" that was undertaken in one's youth. It functioned as a preparatory stage "before starting the serious business of life" (p. 11). For instance, Rury indicates that teaching was considered to be suitable work for women prior to getting married and having a family, while for men it served as a stepping stone for pursuing a career in a more "learned profession" or in business: "As long as teaching 
was largely conducted by young people, it suffered from the persistent image of immaturity and incompetence which perpetuated the notion that teaching was a mere station for men and women intent on bigger and better things in life" (p. 11) (see also Miller, 1996; Prentice \& Theobald, 1991). It is important to highlight, however, that teaching remained one of the only suitable forms of work available to women at a time when they were denied access to all other higher status male professions. From its inception, however, even in colonial America, when teaching was largely the domain of young, White, middle-class males, it was still not considered to be a proper profession and was viewed more as a trade (see Rury, 1989, p. 13).

Rury's historical account illuminates that men have never really conceived of teaching as a legitimate profession. From the start, it was considered to be a stepping stone to more prestigious professions such as law and medicine. This helps to understand the conditions that enabled the rapid feminization of teaching into the 19th century. Given the changing labour market conditions that developed in response to increasing industrialization and urbanization, as well as the development of modern school systems in the 19th century, educated women constituted a labour pool that was needed to fill the teaching positions that were increasingly being vacated by men in pursuit of better paid professions. In short, women teachers were able to move into teaching particularly in those locations where there were few educated males willing to apply for teaching positions.

Thus given the already-inferiorized status of teaching as a profession, its poor salary relative to other male professions and the willingness of men to vacate teaching in search of better conditions, the feminization of teaching initially was not considered to be a threat to male power. Rather, teaching became defined in the popular domain as an extension of women's domestic role in the home in its association with caring for and nurturing children. Moreover, it is important to stress that there were no explicit policy initiatives on the part of school committees to hire women as a cheap source of labour. In short, the urban labour market conditions with men leaving teaching in large numbers simply dictated the necessity of employing women. The point is that women moved into teaching positions out of necessity due to the conditions created by educated males either leaving or choosing to enter better-paid professions (see Rury, 1989, p. 16).

Hence, the increasing feminization of teaching was accompanied by a sexual division of labour grounded in hierarchical gendered power relations, with large numbers of young women being supervised by older men in positions of authority (see Tyack \& Hansot, 1982). In short, a school system emerged in which mainly women did the teaching in classrooms under the supervision of male administrators (see Acker, 1995/96; Altenbaugh, 1992). Thus female teachers were not only discriminated against in terms of being paid lower salaries than men in the profession, but they were also positioned within a gender regime which supported patriarchal power 
and the authority over women (see also Cavanagh, 2005a, 2005b, 2006). Moreover, initially, the fact that women were a cheap source of labour did not deter school committees from actively seeking out male teachers. For some school committees, hiring female teachers was considered a last resort. At the time, concerns were expressed about the capabilities of women with regards to disciplining older boys. The concerns expressed during the initial feminization of schooling in the 19th century parallel those that have been articulated more recently about the need for more male teachers in elementary schools (see Carrington, 2002; Lingard \& Douglas, 1999, p. 80; Martino \& Kehler, 2006):

Male teachers often were valued for their ability to manage unruly rural schoolhouses which typically mixed older and younger children. In more highly developed school systems they were seen as potential role models for adolescent males. In many urban school systems on the other hand, where age grading made classroom discipline less problematic and teachers could be assigned whole classes of younger children, there was greater openness to hiring women teachers. (Rury, 1989, p. 16)

Clifford (1989) provides further insight into the domestic ideology that supported the initial hiring of teachers in the 19th century. However, the increasing feminization of schooling was not entirely unproblematic and did give rise to some concern about the potential emasculating influences of women teachers. Clifford refers to the alarm in 1884 expressed by the president of Chicago's board of education at the growing numbers of female teachers and principals who, apart from being considered "too irritable" and lacking in "self-control," were thought to influence the development of "effeminacy in boys" (p. 296). Moreover, Clifford claims that from 1885 to World War I national magazines and professional journals made reference to the "woman peril" in response to the increasing feminization of schooling which was considered to be "driv[ing] the last man from the field" (p. 298). Furthermore, an apparent backlash fuelled by male school administrators and university professors also appeared to be emerging at the time. These men were afraid, Clifford claims, that the increasing numbers of women who were studying in the newly established teachers colleges would invade their own professions. In fact, Clifford paints a picture historically of increasing panic and concern being expressed as women's presence in schools continued to grow into the 20th century. For example, she claims that "during the great Depression and following the Second World War, strong efforts were made to recruit men back into teaching, in part to protect or restore the patriarchal position of men in the American family, as it was argued that exposure to strong male figures was needed in the socialization of adolescents, especially boys" (p. 298).

This historical legacy is also documented by Abbot (1991) within the Ontario context in Canada who refers to anxieties about the increasing feminization of schooling at the turn of the 20th century. He claims that 
there was a concern that "female domination of the teaching ranks threatened the cult of true manhood" (p. 52). Abbot indicates that school trustees expressed anxiety about the lack of male teachers for boys in schools for fear that it might "tend towards effeminacy and eventually breed a generation more fit to be appareled in petticoats than pants" ( $p$. 52). He elucidates the extent to which the declining numbers of male teachers was considered to be a tragedy resulting in the depletion of "the vitalizing effect of good manhood on the growing young men of today" ( $p$. 53). He highlights the extent to which such patriarchal assumptions fostered a male administrative culture supported by an ideology that positioned men as being not only more effective disciplinarians, but the epitome of "advanced knowledge essential to civilized existence" (p. 68). It is interesting to note that such anxieties about the status of masculinity irrupted or intensified at a time when women's rights were gaining momentum. For example, Faludi (1991) argues that women's rights gained momentum at four historical junctures - mid-19th century, the early 1900s, the early 1940s and the early 1970s-which she claims resulted in various forms of backlash (p. 48). Later manifestations of this backlash in the early 1970 s, as it relates to the feminization of schooling, are discussed in the following section.

Oram (1983), in fact, locates the roots of marriage bans and the subjugation of women teachers in many parts of England in the early part of the 20th century to the backlash of the time, as well as to the rhetoric about the place of married women in the workforce as a means by which to secure patriarchal male privilege (see Acker, 1995/96, p. 117). For example, Oram (1989) documents how marriage bans were imposed by most of the London Education Authority (LEA) school districts between 1921 and 1923 in response to education cuts and rising unemployment rates. Such conditions resulted in thousands of married women losing their jobs, as well as in single women being forced to resign once they decided to marry. During World War II, however, she indicates that the situation changed as a result of concerns regarding teacher shortage, which led to marriage bans being removed under the 1944 Education Act (Oram, 1989, p. 24). This situation paralleled that experienced by female teachers in the United States. For instance, Clifford (1989) writes about the consequences of war which had, she claims, "direct effects upon both sexes' roles in education" (p. 307). She notes that the war required men to participate in military and war-related industries which resulted in vacancies in schools that women filled. In addition, 50,000 American men who left teaching to participate in World War I never returned to their positions in schools because, Clifford claims, they sought better-paid positions in other professions. This scenario, she adds, was repeated with World War II, thus opening up possibilities for married women to enter teaching at a time of teacher shortage, which necessitated the lifting of "long-existing prohibitions" or marriage bans (p. 309). 
However, Oram indicates that despite the eradication of marriage bans and the implementation of equal pay scales in the 1950s, explicit and officially sanctioned sex discrimination was simply replaced with an alternative structure of pay and promotions which indirectly disadvantaged women: "Rather than distributing rewards equally to all classroom teachers, higher salaries were available for a smaller number who could display a (typically male) career pattern of continuous service, managerial and other extra responsibilities and work in larger (secondary) rather than smaller (primary) schools ...” (p. 28). Thus what became institutionalized in the postwar era, according to Oram, was a "deeply familial ideology" which was replicated by the school system with "the man as the head of the family, supported by women teachers, who were supposed to be particularly suited to the education of younger children" (p. 29). As a result of such a patriarchal ideology being enforced, schools simply tended to reflect the structure of sex-differentiated roles associated with the ideal nuclear family:

The most common argument against equal pay was that men needed more money because they had wives and children to support. The ideal of the nuclear family complete with male breadwinner, dependent wife and two or three school age children and its opposite, the self-supporting spinster, was central to sex inequality in the profession and was constantly invoked to justify discrimination against women teachers. (p. 29)

The historical perspective provided by Bhroimeil (2006) in Ireland at the turn of the century also illustrates the extent to which an ideology of female nurturance and hence, sex-role differentiation, underscored the sexual division of labour in schools. Bhroimeil examines the impact of Rule 127 (b), instigated by the National Commissioners for Education in Ireland requiring all boys under 8 years of age to be taught by school mistresses who were considered to be "the most suitable instructors" (p. 36). Such a rule was grounded in the belief that a man "both by temperament and training was unfitted to teach infants" (p. 36) and that women were "the natural guardians of young children" (p. 37). The main objections to such a rule revolved around concerns about the displacement of male teachers who would be supplanted by female teachers. These concerns were located within the broader context of anxiety about the feminization of the teaching profession which, Bhroimeil indicates, had been documented by the Mosley Commission on American schools, an official body organized to investigate the extent to which education in the United States had contributed to "industrial progress" (p. 50). Bhroimeil documents the moral panic in the Irish media at the time, which reported on the alarm expressed by members of this commission who, while expressing concern about the extent to which women were monopolizing teaching, saw the advantage of having young children taught by "the gentler sex" (p. 37). However, Bhroimeil documents public concern about the fear that young boys might be feminised if taught by women. Such a historical account of the femini- 
zation of teaching in Ireland is useful within the context of debates about male teachers because it points to another manifestation of the legacy of women's subordination within a context of backlash and concern about the impact of female teachers on young boys. While Rule 127 (b) allowed for increased employment opportunities for women in Irish schools at the turn of the 19th century, given their supposed innate propensity for nurturance, they were still paid considerably less than their male counterparts.

It is important to highlight that while the phenomenon of the feminization of teaching occurred in various countries, as illustrated above, Prentice and Theobald (1991) point out that the timing of it varied in Canadian provinces and that there were economic, church/state relations and other demographic factors at play accounting for these variations (see also Acker, 1989, 1995/96; Cortina \& San Roman, 2006; Coulter \& Harper, 2005; Heap \& Prentice, 1991; Lawn \& Grace, 1987; Oram, 1989). In addition, these historians claim:

Equally interesting are the questions of class and ethnicity. There is clearly more to learn about the changing social, cultural and educational background of teachers. Did expansion of teaching forces in the nineteenth and twentieth centuries result in shifts in their social class and ethnic composition? The significant participation of working class women and women of colour in teaching raises the question of how their presence influenced not only the sexual division of labour in the occupation but also school boards' treatment of their female employees. (p. 24)

Such analytic and historical perspectives only serve to further highlight the extent to which the call for more male role models is often cast in terms which invoke not only the male heterosexual subject but, more significantly, white male privilege. In short, once the call for more male role models is situated within analytic frameworks that are informed by queer and gender studies (Bland \& Doan, 1998; Britzman, 1993, 1998; Butler, 1993; Harding, 1998; Kendall \& Martino, 2006; Talburt \& Steinberg, 2000), the absence of discourses about whiteness or heterosexuality from policyrelated and populist discussions about male teacher shortage, is highlighted (see King, 2004).

The historical perspectives outlined in this section are informative and useful given the debates about male teacher shortage in elementary schools and the feminization of schooling in more recent times. As Acker (1995/ 96) argues, "the role of rhetoric about what is believed to be properly feminine or masculine can be seen to influence policies in the past and the present" (p. 120). In this sense, bringing such perspectives to bear on the current backlash crisis foregrounds the absence of an analysis of the politics and dynamics of gender relations as they pertain to both the devalued status of doing women's work and the implications of this for addressing policy-related issues of masculinity and patriarchal privilege. For example, as will be demonstrated in the following section, the emergence of the 
feminization of teaching historically has always aroused some level of concern at both the level of women's subordinated status relative to men in the labour market and in relation to questioning both a male classroom's teacher's masculinity and gender deviance in female teacher's expressions of gender non-conformity (Cavanagh, 2005a, 2005b, 2006).

\section{Same-Sex Desire and Gender Non-Conformity in Teachers' Lives}

Blount (2000) offers another significant dimension to this historical analysis of the impact of feminization on the status of teaching, which foregrounds the extent to which same-sex desire and gender variance or gender non-conformity provoked deep anxiety about the professional and moral status of the teacher (see also Cavanagh, 2005a, 2005b, 2006). She foregrounds the role that homophobia played in the policing and perpetuation of rigid gender roles for teachers in the 19th and 20th centuries, which related to cultural taboos of the "single woman" and the "effeminate man" as transgressors who displayed deviant sexualities. For example, she claims that men who remained in primary school classrooms as teachers "risked reputations as effeminate men" as a result of working in a field that had become predominantly identified as "women's work." As will be illustrated in the following section, this parallels concerns and fears that continue to be expressed by male teachers and within the context of the public media in the $21^{\text {st }}$ century. It raises important issues surrounding what Blount refers to as "cross-gender behaviors and characteristics," the consequences of which are intensified for both unmarried men and women historically who chose to do "women's work" or who defied cultural norms governing socially acceptable manifestations of embodied heterosexual masculinity and femininity (p. 84). For example, she claims that the first women teachers were considered to be "masculine, independent and lacking in feminine qualities." In addition, with the increasing feminization of teaching into the late $1800 \mathrm{~s}$, men who taught children were "widely regarded as effeminate and submissive" (p. 85). Thus gender transgression in the form of defying cultural norms for doing masculinity and femininity lie at the heart of the feminization of teaching and resulted in casting both men and women as lacking and/or deviant. As Blount states, "Properly masculine men would leave the toils of the classroom for the rough and tumble world of work with other men" (p. 85).

Blount reiterates, however, that there was a struggle for men who remained in teaching to redefine or rather to bolster their "flagging sense of manliness" (p. 86). One of the strategies involved attempts on behalf of male teacher associations and societies in the early 20th century to recruit more male teachers in order to increase the presence of men in schools. For example, Blount indicates that in 1911 male teachers and principals in New York launched a campaign to attract men into elementary teaching 
because it was thought that an absence of men in elementary schools produced effeminacy in boys (p. 86). This campaign to entice men into teaching, Blount claims, was also evident 2 decades later with the all-male education society of Phi Delta Kappa distributing pamphlets designed to encourage male students to enter teaching. Another strategy in the early 20th century also entailed masculinizing schoolwork through creating male-dominated niches in schools with administration, sports coaching, vocational education, and subjects such as manual trades, maths and science being designated as male-identified domains or niches. Men in administrative positions in schools were considered to be more suitably masculine and "less subject to "defects"' (quoted in Blount, 2000, p. 86). Due to the overall aversion expressed by men for women's work, Blount states that they actively sought superintendents positions which removed them from the everyday feminized world of schools and into a role more consistent with the norms dictating the exercise of masculine power. With the growth of universal schooling, school superintendents were removed from schools taking up their administrative positions in central offices away from the schools and closer to municipalities and local business districts. The classroom where "women typically served," Blount argues, became removed from the world of the superintendent which developed physically as a separate male sphere of work (p. 86).

Within such a gender hierarchical context of labour relations within the education system, those men who remained in schools "doing women's work" increasingly risked being stigmatized as sissies or effeminate men. Blount accords such social stigma a particular significance in terms of accounting for the declining number of male classroom teachers. By 1920, she claims that male teachers and administrators in schools comprised only $14 \%$ of all education positions in schools (p. 87). The Atlantic Monthly is cited as reporting, in a vein that smacks of the current moral panic and backlash surrounding the issue of male teacher shortage, that in "half the cities of the United States there are virtually no men teaching" (p. 87). Thus, Blount asserts: "Clearly, by the turn of the century the gender definition of schoolwork had shifted so dramatically that men could transgress their gender-appropriate boundaries simply by wielding chalk" (p. 87).

It is important to reiterate, however, that conditions for male teachers who remained in schools also altered in the postwar era. While earlier in the 20th century, effeminate male teachers were considered undesirable because of their inability to provide adequate role modeling for adolescent boys, by the mid-20th century, Blount claims that effeminacy had become an indicator of homosexuality. Earlier, the psychologist Stanley Hall had already argued that the feminised profession of teaching actually produced effeminacy in "properly masculine men." Moreover, he believed that working so closely with women could result in "some deterioration in the moral tone of [male teachers'] virility and [loss of] power to cope successfully with men” (Hall, in Blount, 2000, p. 91). There was a powerful sense 
that, for "real men," working in a feminised profession actually resulted in some form of contamination of their masculinity. Moreover, identification of effeminate behaviour as a signifier of homosexuality in male teachers and, hence, their moral degeneracy, incited public concern which was expressed in terms of a recruitment discourse about "transmit[ting] abnormal attitudes to their pupils" (Waller, quoted in Blount, 2000, p. 91). The use of language such as "transmit," within the context of a public discourse about the threat of homosexuality, foregrounds the extent to which the latter was equated with the spread of an infectious disease.

Compounding this fear was the popular belief that gay men were particularly attracted to certain professions such as teaching because of their need to compensate for the lack of a wife and, hence, the satisfaction of "home life." According to Blount, by the mid-20th century, gender nonconformity actually functioned as a powerful mechanism of social control and surveillance of male teachers' sexuality. This emerged at a time when male teachers were being required or rather incited to provide "correct gender modelling" for the children they taught (p. 92). Blount provides details of national campaigns in the 1950s and 1960s that were mobilised to advocate for the recruitment of male teachers as "proper male role models" in schools. This needs to be understood within the broader context of the fear of the contaminating effects of the feminization of teaching on both boys and the men who chose to work in a femaledominated profession. Driving such a fear was the emergence of the association of effeminacy with homosexuality and the threat that this posed to the regime of hegemonic heterosexual masculinity at a time when it was difficult to attract men into teaching. This parallels the current "moral panic" about the need for more male role models to address the problems boys are experiencing today and which are attributed to the increasing feminization of schooling (see Ashley \& Lee, 2003). Thus, this phenomenon of moral panic needs to be understood within a broader sociocultural context of changing gender roles and the threat that the increasing independence of women continues to pose for the dominant social order of hegemonic heterosexual masculinity.

This pathologization of the teacher on the basis of gender variance or gender non-conformity is further highlighted by Cavanagh (2005a, 2005b, 2006) who also draws explicitly on gay, lesbian and queer studies to address issues of masculinity and gender deviance as they relate to the sexuality of the female teacher in postwar Ontario, Canada (see Bland \& Doan, 1998; Faderman, 1998; Vincinus, 1985). She illustrates how following World War II, through the imposition of marriage bans, female teachers were required to remain single and chaste. However, by 1950, through the intervention of mental hygienists, parents, teacher federations, school administrators and psychologists, Cavanagh (2005a) claims that female teachers were required to adopt a gender and sexual identification that confirmed normative heterosexual femininity. 
Such accounts are important because they further highlight the extent to which the labeling of both male and female teachers' bodies and desires needs to be understood within a context of heteronormative and regulatory social relations that are governed by the "impulse to normalize" driving the classification of the pathologized gender variant teacher (Bland \& Doan, 1998; Britzman, 1998; Halberstam, 1998; Harding, 1998; Sears, 1999; Sykes, 2004; Talburt \& Steinberg, 2000). For example, Cavanagh's historical analysis highlights how the declining status of the single female teacher in the post-World War II period was related to anxieties about their failure to conform to dominant norms of heterosexuality. In short, failure to adopt conventional embodied expressions of femininity translated into fear about female homosexuality and, hence, cast the mannish female teacher as a deviant subject (Cavanagh, 2005a, p. 112; see Halberstam, 1998). In this sense, the potential of the female body to signify masculinity was read as a malady pertaining to the teacher's maladjusted (hetero)sexuality (see also Cavanagh, 2006). In addition, Cavanagh (2005a, 2006) highlights the extent to which knowledge produced by sexologists and psychologists in North America in the postwar period was employed by educational experts to legitimate and attribute a pathologized status to the single female teacher. This enabled her to be cast as a latent homosexual, a mannish woman or simply an emotionally and psychologically maladjusted individual.

These historical and analytic perspectives draw attention to the role that gender normalization and enforced gender differentiation play, particularly in backlash contexts where the forces of re-masculinization are at play vis-à-vis the status of heterosexuality and male privilege. While current debates about male role models tend to invoke male elementary teachers and boys as victims of feminization, and, as a consequence, prone to emasculation, what is eschewed is a more nuanced analysis of the impact and effect of heteronormative systems of hegemonic masculinity and surveillance in terms of determining both the status of the profession and the legitimate or deviant identity of the teacher. Such nuanced analytic perspectives have not been drawn on in the relevant policy related discussions pertaining to call for more male role models. Rather what has been asserted within the context of debates about male shortage is a cultural project of re-masculinization that amounts to invoking the White adult male heterosexual subject as the idealized role model capable of ameliorating the social ills inflicting boys' social and academic well-being in schools. It is in this sense, as Britzman (1993) argues, that invoking male role models fails to address "the problem of either white supremacy or male supremacy and how this deadly combination works to define differently the imperatives of masculinity and femininity" (p. 37). Thus historical accounts informed by analytic perspectives that trouble the "impulse to normalize" draw attention to issues not only of gender, but illuminate the colonizing influences of regimes of dominant White heterosexual masculinity and 
their institutionalization and legitimation through mobilizing policyrelated discourses in response to the feminization of schooling.

\section{Sexton's Feminised Male Teacher}

Sexton (1969), a sociologist who set out to study the impact of the feminization of boys and men, provides another exemplary instance of the historical legacy of backlash. Connell (1996, p. 207) for example, identifies a "minor panic" at this time in the United States about schools destroying boys' culture, which he argues, was attributed to the influence of a femaledominated environment of elementary schools and to "feminine, frilly content" of the curriculum (see also Lingard \& Douglas, 1999, p. 80; Titus, 2004). This question of growing anxiety about the impact of feminization on boys and male teachers has also been identified in the Progressive Era by Green (1991) who explicitly comments on "the worry over the boy problem" (p. 663). For instance, Green claims that as girls began to outstrip boys, and as increasingly more boys left school to enter the labour market, anxiety arose over "the woman question"- the "risk that education would become feminized because of the disproportionate number of female students and teachers" (p. 663). It is also important to note, as Petersen (1998) points out, that the 1960s and 1970s was a time in which the "second wave feminist critique of the dominant heterosexual order" had gained momentum (p. 36). In fact, Petersen argues that historical accounts which are committed to making explicit the links between the dominant heterosexual order and the dominant gender order are necessary and important in challenging the idea that heterosexuality and heterosexual desire are inextricably bound to a fixed gender identity (p. 36). Hence, the purpose of the critique undertaken in this section is to draw further attention to the recurrence of the phenomenon of gender anxiety as a response to broader challenges about the normative status of masculinity.

Sexton's (1969) book, The Feminized Male, captures the preoccupation with the feminization of schooling and its impact on boys' and male teachers' masculinity during the 1960s and 1970s, which resonates with earlier concerns about effeminacy and gender deviancy. In fact, Sexton's response to the feminization of schooling and men/boys parallels the resurgence of a "masculinity crisis" that typifies much of the "moral panic" surrounding the male teacher/boys' education debate which continues to re-surface in more recent times (Martino, 2004; Martino \& Kehler, 2006; Mills, 2003). These sort of responses need to be contextualised within historically specific milieus of social change in which challenges to the established male order are manifested through an intensification of anxiety surrounding the expression and/or definition of "proper" masculinity (see Petersen, 1998). For example, the problem with Sexton is that she equates feminization with female dominance over men, claiming that it occurs "as males fall under 
the dominance of women who have been consigned to home and school (p. 18). In fact, for Sexton, women-both mothers and female teachersemerge as potential figures of fear and loathing in their capacity to castrate and, hence, emasculate men and boys.

For Sexton, this supposedly has particular devastating psychological and emotional consequences for both boys and for male teachers, particularly within feminizing contexts such as school that threaten "normal masculine growth." She argues that the school enforces a form of passive conformity, which is equated with femininity and conflicts with the natural expression of healthy masculinity. This results in rebellion and anti-social behaviour, she argues, leading boys to be cast as "outsiders and misfits" and as "stunted in normal masculine growth" (pp. 10-11).

According to Sexton, this also has a particular impact on many males who are attracted to teaching. These men, she claims tended to be more feminized than normal men or "neuter in gender." They are also represented as having a "rather feline quality ascribed commonly ascribed to women" and as "mama's boys gone bad" (p. 38). While not all men are feminised, they are still constructed as emotionally disturbed or unstable as a consequence of having repressed their masculinity. They are also constructed as dealing with conflict by resorting to "biting and scratching their rivals" verbally and in a manner that Sexton claims is a personality trait associated with women (p. 39). For Sexton, however, this behaviour is linked to these men's experiences of enforced submission as boys to a dominating mother figure who denies their natural expression of masculinity. The result, she claims, is a disturbance that is felt at a deeply psychic and emotional level, which is ultimately manifested in what amounts to an expression of a lack of proper masculinity.

The effects of such female power are also manifested in schools, which Sexton claims, while largely run by men, are "essentially feminine institutions" (p. 29). She elaborates on this by stating that the norms for behaviour in schools are set by women and in this sense boys are forced to adopt feminine standards if they are to be successful in schools. This involves presenting oneself as "polite, clean, obedient, neat and nice" (ibid.). It is in this sense that, for Sexton, "real boys" or rather "the masculine types" have "a tougher time in school than those who look and act more like girls": "I have felt that school makes sissies out of many boys and feminizes many more by insisting that they act like girls" (p. 55). The pejorative overtones are conveyed here through language which highlights a distaste for enforced submission under the exercise of power wielded by women in schools. This use of power is tied to women's repressed anger in response to being denied proper access to other sites of male domination in the workforce (p. 24) and can lead, according to Sexton, to women exerting an influence on men and boys in the home and school that she considers to be poisonous: “. . . women are rather like an essential chemical in the body; either too much or too little can be lethal" (p. 153). For Sexton, such 
conditions explain the phenomenon of "maternal dominance," which is "more likely to produce femininity and homosexuality among boys than maternal overprotection, affection, or aggression" (p. 101). Ultimately, this leads to boys" "normal masculine growth" being "retarded" and causes them to come into conflict with themselves and/or others (p. 135).

In this sense, Sexton argues for the need to address the exclusion of women from "man's work," which, while protecting certain male privileges, has also had a detrimental impact on men: "As a corollary to this, the exclusion of women from the "power structure" of the society-all the places where important decisions are made-has tended to dehumanize and sterilize most of our social institutions and seriously degrade the quality of our lives" (p. 134). Thus, Sexton advocates the masculinization of schooling as a necessity for ensuring "normal masculine growth" for boys, while simultaneously calling for the need to "feminize the power structure of the society" (p. 135). This would produce, according to Sexton, a "new balance" or rather a "balancing out the sexes so that they don't corrode any one spot where they concentrate" (ibid.). Hence, she asserts that increased numbers of any one sex in a particular domain must always run the risk of increased masculinization or feminization which results in some form of "unnatural flow of power." This, Sexton argues, has detrimental effects for both women and men. Such a premise is at the basis of Sexton's call for more male teachers as role models in elementary schools, whom she argues are needed to enhance boys' masculinity, given that women teachers far outnumber their male counterparts. However, she is quick to assert that not any man will do- "real men" with their uncontaminated masculinity intact are required. This is significant in terms of a shift in focus from support for the feminization of schooling, as an extension of the domestic maternal role in the previous century, to a focus on a rejection of the feminization of schooling as a site for the projection of a fear and loathing of female power, with its concomitant emasculating effects on boys' and men's identities and lives. The effect of this is to reinforce dichotomous gender categories with masculinity and femininity being sharply defined in oppositional terms (see Harding, 1998; Petersen, 1998).

Such responses to the feminization of schooling and, hence, the emasculation of boys and men, need to be understood as a response to broader social changes of the time in terms of the impact of the second-wave feminism and gay/lesbian rights/activism within the context of the sexual revolution and its impact on the changing roles of men and women in society. For example, while Sexton calls for the need for women to move into male-dominated labour markets and domains and challenges sex inequality at this level, she still resorts to enforcing gender normalization and, hence, a gender regime built on the dichotomization of masculinity and femininity as essentialised identity or role categories. This leads her to argue for the need to counteract the heinous influences of the feminization of schooling in favor of remasculinizing teaching and the curriculum 
to make schools more "boy friendly." This very argument, in fact, is at the heart of current reform agendas for boys' education that are being propagated in contemporary times (see Martino, 2004, 2006; Martino, Mills, \& Lingard, 2004). For instance, Sexton, resorts to a recuperative masculinity politics similar to that reflected today within the context of the boys' education debates and moral concerns about the lack of male role models in elementary schools. These concerns may be summarized in terms of the following:

1. The need for more men in schools to counteract the detrimental influences of the feminization of schooling. (The difference is that Sexton is explicit in her assertion that not any man will do!: "The quantities of females and the scarcity of 'male' men make the school inhospitable to masculinity" [Sexton, p. 191]).

2. The need to masculinize schools and the curriculum to cater for boys' learning needs that are linked to the natural expression of masculinity.

3. The sense that schools are not "boy friendly" and favor girls or female ways of knowing. ("Both boys and girls seem aware that teachers favor girls and are more disapproving of boys” [Sexton, p. 191]).

4. The sense that schools enforce passive learning and, as a consequence, tend to accommodate girls' rather than boys' learning needs.

An analysis of Sexton thus highlights how the issue of the feminization of schooling functions within a context of recuperative masculinity politics and backlash that parallels the moral concerns currently being expressed about boys' education and male teacher shortage. Advocates of boys' education and male role models are aligned ideologically in resorting to assertions about the need to recuperate "normal" masculinity which is conceptualized as a natural expression of a biological sex difference. According to Sexton, the problem is that the failure to provide role models for boys in female-dominated elementary schools has dire consequences for impeding the natural expression of masculinity. Given such conditions, she calls for the need for men to "assert what residual masculinity is in them" (p. 191).

\section{Representations of Male Teachers in the Popular Media: A Contemporary Snapshot}

Such histories of the feminization of teaching foreground the politics of doing women's work in terms of both its potential threat to dominant masculinity and its devalued status as an occupation. This legacy of teaching as women's work continues to be manifested today in the rhetoric espoused by the public media and official government bodies that resort to calls for more men in schools to rescue failing boys and to recuperate their 
masculinities (Martino, 2004; Martino \& Kehler, 2006). The impact of such discourses is captured nicely by Kimmel's (1993) account of his own experiences of teaching at a nursery school. He writes about a quiet, shy boy named Brad, who loved to paint at the easels that had been set up in the classroom. While other boys would rush to engage in more stereotypical forms of gender play, Brad would choose to paint. Kimmel mentions how overjoyed Brad's parents were when they first learned that their son was to be taught by a male teacher. The fact that he was a man doing women's work meant in their eyes that he would be able to "rescue their son from a life of gender non-conformity" (p. ix). Thus, there was a sense that a male teacher might be able to help their son develop his masculinity along more normative lines.

In this section, I contribute further to the existing literature by identifying the manifestation of anxieties and concerns expressed about the dearth of male teachers as they emerge in the popular media in the United States and Canada. For example, Pepperell and Smedley (1998) document media representations of male teachers as "an endangered species" in the United Kingdom (p. 341). Foster and Newman (2005) also illuminate the role of the media in perpetuating unproblematized notions of role models within the context of fuelling moral concern about the feminization of schooling, particularly for boys from single-parent families where the father is absent (p. 342). This is further supported by Burn (2001) who documents the media's representation of the predominance of female teachers in the United Kingdom. This is expressed, she demonstrates, in terms that emphasize concern over the lack of positive role models for boys which contributes apparently to "making boys feel inferior" (p. 3). In fact, Pepperell and Smedley (1998) argue:

Concepts of role model and socialization theory are widely challenged in the literature on gender, but used rather unproblematically in the "common-sense" comment around teacher recruitment in the press. (p. 344)

This critique is further supported by analysis of media reports dealing with teacher recruitment and male teacher shortage in Australia, the United States and Canada (see Martino, 2004; Martino \& Kehler, 2006). However, as Anderson and Accomando (2002) argue, the tendency to subscribe to essentialist and universalizing assumptions about gender and sex-role socialization "make for a faulty foundation from which to examine gender" (p. 491). While there is a potential within the context of these debates to examine the ways in which male teachers and boys simultaneously benefit from and are constrained by gender polarization and normalization, for the most part such analytical perspectives and insights have been foreclosed. Rather what is often invoked in the press, for the most part, is a moral concern about the lack of male role models in elementary schools which is enhanced by what is perceived to be an increase in single-parent 
families. This adds a further moral dimension to claims about the need to bring "some gender balance to an environment known for and dominated by its female faculty" (see Cativo, 2006). ${ }^{2}$

Higgins (2002), a journalist writing for the Detroit Free Press, for example, quotes a special education teacher in Kentucky, who reiterates this view that the teacher crisis is compounded both by a lack of males choosing to enter the teaching profession and by a perceived increase in single-parent families: "We make up the most visible minority around. And we recognize that these guys are important in these positions because in most places they are role models for kids who don't have both parents at home." This is further reinforced by a statement from the director of a teacher recruitment program at Marygrove College which aims to attract African-American males: "Because of the type of crisis we have in urban communities ... some of them are coming from homes where they have never known what it means to have a man in their life." These sorts of claims are couched within a broader context of "the need to diversify the historically female dominated teaching profession" with reference being made to a supposedly growing body of research which "shows that dad's involvement means their kids do substantially better in school." For instance, both the National Education Association (NEA) and the National Parent Association are both presented as "waging drives for men in their ranks." The crisis is foregrounded by the fact that colleges of education "have a tough time luring men" and this is attributed to the notion of teaching as a feminised profession or, as Higgins claims, to "dated notions that teaching is women's work and because many men don't see the profession as a lucrative way to provide for their families." The unquestioned assumption at the basis of such claims is driven by an ideology which supports the traditional nuclear family structure with the notion of the male as the chief breadwinner.

This discourse of moral concern about the dearth of male role models and the impact of feminization also emerges more explicitly in a story filed by NewsCentre16 reporter Jennie Runevitch (2003) for WNDU-TV in South Bend, Indiana. The journalist claims that "Men are in the minority in education and now the National Education Association (N.E.A.) is sounding the alarm that more male teachers are needed." The problem is framed not so much in terms that address the issue of providing quality teachers, especially in high-need school districts (Ingersoll, 2001), but rather collapses into a discourse of moral concern about the need for more male role models in children's lives: "That means classrooms don't accurately reflect society and it means more children are without male role models." Throughout the report male elementary school teachers are referred to as "rare commodities in the classroom" because they are working in a "femaledominated profession" with the number of men in the elementary school classroom "shrinking to an epidemic low just nine percent."

This leads once again to the familiar tendency in the populist media to resort to essentialised gender differences as a basis for advocating the need 
for more male role models. According to Runevitch, apparently the change is evident both "in and outside the classroom." For example, reference is made to two male teachers who spend their breaks "bonding with students as quarterbacks for the recess football league." A particular normalized and heterosexualized masculinity is invoked in relation to how men are represented as gendered subjects. They are presented as being able to relate to children in ways that are essentially different from how women supposedly teach. Through sport, which by implication is understood as "a masculinity confirming practice" (Renold, 2003), men are able to demonstrate an expression of masculinity that fits with the dominant culture's conception of what it means to be a normal man. Within this feminized context, where such expressions of natural masculinity are supposedly denied, the few men who enter the profession are constructed as victims of externally imposed stereotypes: "There are the stereotypes to contend with, there is the misconception that men aren't nurturing enough and that elementary education is women's work. Some men fear they'll be branded as pedophiles for working children." Suffusing this discourse is the moral concern that such stereotypes are preventing men from entering the profession and the result, according to this journalist, is that children are being "deprived" of male role models "in an age when single parent homes are so prevalent." The solution, however, is one that always amounts to affirming the re-masculization of boys and, hence, legitimating the very gender-polarized system that imposes such constraints on men's expression of and understanding of masculinity in the first place.

The tendency to support such a system of gender polarization is further reflected by Binks (2006) in Canada who claims that

Strong male role models seem more necessary than ever these days. Many boys are struggling in schools and some people feel the male teacher shortage is contributing to that situation. As well, of the 1.3 million single parent families, 1.06 million are headed by women. A male role model would certainly come in handy.

This represents a familiar tendency to invoke essentialist notions or assumptions about gender as a basis for advocating pedagogical practices that are consistent with catering for the perceived learning and social needs of boys. In fact, Orlando (2005) indicates that "Many educators believe that because men and women have different styles and approaches to teaching, a more balanced mix of female and male teachers in early grades will be of great benefit to students as they advance into middle grades and beyond" (see Martino, 2006, for a critique of the Australian government's endorsement of such positions). This captures the logic driving much of the educational policy formulation and discussion pertaining to the need for more male role models in elementary schools (see House of Representatives Standing Committee, 2002; Ontario College of Teachers, 2004). It also highlights the ideology of gender polarization and normalization that 
dominates much of the discussion about the role and impact of male teachers in terms of their pedagogical practices and relations with students.

This is further reiterated by Orlando (2005), journalist who reports on school districts in the United States committed to attracting more men to "a career field that has always been dominated by women." She quotes the director of a recruitment program for African-American male teachers called Call me MISTER, which has been developed by Clemson University in South Carolina. He claims: "There's just a difference-whether it's in style, voice intonation, just the presence of having a male in the classroom-that many boys respond to best." This is supported repeatedly by journalists who prefer to quote sources who reiterate the need for male teachers based on the taken-for-granted assumption that they are simply men and, hence, essentially different from women. For example, another journalist, Bolch (2006), quotes a national educator who claims that "it is frustrating that more men don't enter the field because men and women bring different but complementary approaches to classes." In addition, MacDonald (2003), writing for an independent daily news article in Boston, claims that "many children without a father crave a male presence in the predominantly female domain of elementary school" and consequently "need what men have to offer uniquely as men." This notion that "men bring a different perspective to the classroom" is reiterated throughout the report and supported by quotes from or reference to teachers who claim that (1) "Boys are apt to suffer when codes of conduct reflect the sensibilities of an all-female faculty"; (2) "Female colleagues expect children to work quietly in their seats most of the time and to keep noise levels down but men don't expect quite as much serenity from children"; (3) Male teachers are better at disciplining boys because "boys accept male authority better than female authority" (see Martino et al., 2004, for a critique of such sexist viewpoints and their manifestation in terms of advocating for a boy-friendly curriculum in schools). Invoking discourses about an essentialised maleness is at the heart of such advocacy which represents a deeper, albeit unspoken, anxiety about the need to assert or reclaim masculinity for boys who are considered to be at risk of being feminised and misunderstood by female teachers in a female-dominated world.

The familiar strategy is to resort to reinforcing and legitimating gender differences that are linked to binary categorizations of the sexed body (Harding, 1998). As Petersen (1998) points out, the tendency to invoke such forms of gender dimorphism have arisen at historical junctures in response to a crisis of masculinity where men's position of power was being challenged (see also Blount, 2005). This enables a deeper understanding of the tendency to resort to gender dualistic frameworks as a means by which to reinscribe traditional and stereotypic notions of masculinity that leave unquestioned the power relations at the basis of forming such an oppositional gender identity (see Anderson \& Accomando, 2002). Under the guise of advocating for a more gender-balanced profession, the issue of 
reinstating hegemonic power relations is established through mobilizing discourses which position men as essentially different to women. Such positions acquire the status of common-sense truth claims and eschew any discussion about the constraints of gender polarization and male privilege within the context of doing women's work with its legacy of sexism, misogyny and homophobia. As a consequence, the limits imposed by policing the boundaries of acceptable masculinities and femininities for both male and female teachers are never addressed (see Blount, 2005; Cavanagh, 2005a, 2005b, 2006; Martino \& Frank, 2006).

\section{The Impact of Masculinity on Male Teachers' Identities and Pedagogical Practices}

Within the context of educational policy discussions and reports in the popular media there has been a decided absence of reference to research based literature dealing with the impact of hegemonic heterosexual masculinity and its impact on male teachers' perception of doing women's work, as well as how it influences pedagogical relations and practices in schools. Rather, certain populist notions about men and boys, which rely on evoking gender polarization as the basis for understanding the development of identity formation, gain the status of unproblematized truth about what it means to be properly masculine (see Anderson \& Accomando, 2002; Lingard, 2003; Mills, 2003). Such discourses, as I have illustrated in this article, authorize particular knowledges and ideological standpoints about male teachers as role models, which have resulted in a failure or rather refusal to engage with research-based literature that raises serious questions about the limitations of this project of remasculinization, as it has been manifested within the context of men doing women's work in elementary schools (see Carrington, 2002; Coulter \& McNay, 1993; Martino \& Frank, 2006; Martino \& Kehler, 2006; Mills et al., 2004; Roulston \& Mills, 2000; Sargent, 2005; Skelton, 2002; Williams, 1993). For example, Williams (1993) claims that "men use various strategies to maintain their masculinity in [female-dominated] occupations, often transforming the work in the process" (p. 6).

This raises important issues surrounding what Bradley (1993) terms damaged masculinity for those men who enter such occupations, but also creates, she argues, the potential for encouraging men to disrupt conventional stereotypes about what it means to be a man leading to the "development of new masculinities" (p. 25). According to Bradley, we need to understand these practices of negotiating masculinities within a context of de-gendering and re-gendering social relations and capacities that have been ascribed to women. This necessarily involves, given the historical legacy of the feminization of elementary school teaching, the need to interrogate and dismantle "structures of sex-typing": 
Men themselves will also need to change, in working to rid themselves of expectations of superiority to women in terms of status, authority, and rewards, and in contributing to a revaluation of caring and interpersonal skills and the challenge to hegemonic versions of masculinity. (p. 25)

An emerging body of literature in the field, however, provides evidence of hegemonic masculinity being supported rather than challenged by male teachers in schools. Roulston and Mills (2000), for example, provide empirical evidence to suggest that male teachers regularly reinforce ways of being male through their relationships with boys and approaches to teaching. For example, they focus on accounts given by male teachers about their approaches to working with boys and also draw attention to the role of male teachers working in feminised areas of the school curriculum. Rather than adopting a position of challenging dominant ways of being male, these teachers sometimes tended to reinforce gender-stereotypical behaviours in boys. For the two Canadian male music teachers discussed in this research, music was constructed as a feminised activity and this was related to their fears of being perceived as "soft" or "feminised" which led them to adopt particular ways of being male in the classroom to assuage any doubt about their status as "real men." This, Roulston and Mills illustrate, was behind their compulsion to prove their masculinity, rather than to challenge dominant understandings about what it means to be male. For instance, one of male music teachers adopted a position of reasserting that he was "not a fairy" to counteract the association of singing with homosexuality. He also made a point of announcing that he coached floor hockey and basketball and was emphatic about his involvement in these male sports to counteract any implied association of music teaching with being gay. This raises questions about the role that male teachers might play in reinforcing certain problematic behaviours and ways of being male for their students in an attempt "to distance themselves from femininity and unmanliness" (Roulston \& Mills, 2000, p. 234; see also Martino \& Frank, 2006).

Skelton's (2001) research in the United Kingdom also points to the very significant ways in which male primary school teachers feel compelled to present themselves as "properly masculine." Because schools are perceived to be female environments, this may involve, she argues, "exaggerating various aspects of masculinity and thus presenting themselves as 'laddish' through using humour and demonstrating a passion for football ...” (p. 138). She provides additional evidence to support these claims about male teachers. She found that "male student teachers of upper primary children were more likely to be concerned about and supportive of traditional images of masculinity than those men who were training to teach lower primary grades" (Skelton, 2003, p. 195). This study is undertaken within the context of highly charged and politicised context in the United Kingdom with the government's drive to recruit more male teachers in primary schools to combat the "laddish" behaviour of boys. This strategy, Skelton stresses, is based on limited sex role socialization theories "whereby 
masculinity and femininity are located solely within male and female bodies" (ibid.). Rather than resorting to simplistic role model theories as a rationale or justification for advocating the need for more male role models, Skelton (2003) calls for a more sophisticated knowledge base which gives "some consideration to the fact that "masculinity" and "femininity" is not simply a property of bodies but is intertwined into the daily management and organisation of primary schools" (p. 207).

King's (1998) research in the United States sheds some further light on the ways in which masculinities are intertwined with male elementary school teachers' pedagogical practices. At the heart of this nexus is the issue related to the perception of elementary school teaching as a caring, nurturing practice (see also Williams, 1993). It is this construction of teaching as a "gender-inscribed social behavior," King argues, that produces anxieties for male teachers, whose masculinities often get placed under a particular kind of normalising surveillance (p. 5). This, he points out, may also explain why some men choose not to enter the teaching profession. This practice, of male teachers adopting a culturally validated hegemonic form of masculinity to assert their normalcy, is read by King as an attempt to ward off any association of deviancy surrounding the "unnamed, silent accusation of pedophilia" (p. 6) (see also Berrill \& Martino, 2002). Thus, this association of effeminacy with gay sexuality functions as a homophobic strategy to position all gay men as potential sexual deviants and emerges as a significant influence in male primary school teachers' lives in King's research.

It is at this nexus of male teachers negotiating masculinity that Allan (1994) provides a more nuanced understanding of the dilemmas and anxieties faced by male elementary teachers' pedagogical relations with students than that revealed in current discussions about male teachers by education policy makers and stakeholders (Elementary Teachers' Federation of Ontario, 2003; House of Representatives Standing Committee, 2002; Ontario College of Teachers, 2004). Allan (1994) investigates the meanings of role modelling for male teachers and the broader community in the United States. He raises crucial questions about the pressure on male teachers by parents in the broader community to act as role models, particularly for young boys. Male role modelling, Allan claims, is tied in to men's perceptions to the breakdown of family and indirectly to social problems of adult males' which resulted in several of the male teachers in his study feeling pressure to take on the role of "surrogate fathers" in proving strong discipline (p. 6). For some of the male teachers he spoke to, this created a burden, and challenges the whole discourse of idealization surrounding the appropriation of role modelling as the panacea for addressing the problems that boys are experiencing in schools (see Martino et al., 2004; Mills et al., 2004).

In fact, several male teachers, while acknowledging the advantages for men of being hired as teachers on the basis of their minority status, also 
expressed some confusion or uncertainty about what role modelling actually entailed and, moreover, what it actually meant, despite the fact that there appeared to be a tacit agreement that it involved "an optimistic ritual approach to solving social problems" and, hence, constituted a particular pedagogical relation and practice governed by norms about "being a man" (p. 9). This led to conflict for some male teachers in terms of experiencing a contradiction of feeling compelled to behave as a male role model "defined oppositionally as doing nothing feminine," while being required to undertake work considered to be the domain of women: "Paradoxically, a recurring theme among the men I interviewed was the awareness of public perceptions...that teaching children was not an occupation a competent "real man" would willingly choose" (p. 9). This was manifested for the men in terms of a perceived need to guard against any charge of effeminacy and hence, association with homosexuality. Thus, male teachers must navigate their way between an array of hegemonic and subordinated masculinities (Connell, 1995) organized around negotiating their engagement in "unfeminine activities"-being the strict surrogate father able to enforce discipline-while simultaneously demonstrating their capacity to nurture empathic caring relationships with children. The horns of such thorny dilemma and the sanctioning of dangerous or poisonous pedagogies that both extremes pose for male teachers-aggressor versus pedophile-require much more sophisticated analysis of sexuality and gender relations than that offered by current educational policy makers and stakeholders. As Sargent (2005) argues, male teachers may "find themselves caught between doing a subordinated form of masculinity that would make them successful teachers and structural demands for them to do a form of complicit masculinity that is more supportive of the patriarchal gender regime" (p. 253).

Foster and Newman (2005) identify a similar polemic amongst males training to be primary school teachers in the United Kingdom who experienced a form of what they term "identity bruising" which they attribute to the "common sense beliefs that primary teaching is an unsuitable job for a man" (p. 347) in that "a man teaching young children is not a masculine thing to do" (p. 351). This was manifested for these men in terms of pejorative comments from family and friends about their decision to study primary teaching. However, suggested strategies to recruit male teachers such as those proposed by the Elementary Teachers' Federation of Ontario (2003) fail to address the culture of hegemonic masculinity that leads to such "identity bruising" and which accounts for the denigration and devaluing of elementary schooling as "women's work." On the basis of their research with young men about their attitudes to elementary teaching as a career, the issue of the perception of elementary school teaching as a female occupation is identified as significant for many participants. They also claim that they had not "come into contact with any information about becoming elementary teachers." According to the Elementary Teachers' Federation of 
Ontario, encouraging males to become elementary school teachers must involve disseminating more accurate information about teachers' salaries and the benefits of working as an elementary school teacher. In addition, recruitment needs to involve "practising male elementary school teachers sharing more information about their work with young people they know" (Elementary Teachers' Federation of Ontario, 2003).

This amounts to a neo-liberal interventionist attempt to address the problem of male teacher shortage and recruitment which amounts to profiling male elementary school teachers who by implication can present a different face to "doing women's work." Thus, in expressing concern about the lack of a gender balance in elementary school teaching and, hence, the need for teachers "to reflect a cross-section of the society," the Elementary Teachers' Federation of Ontario (2003) misses an important opportunity to raise crucial questions about the system of gender relations driving the negative perception and devalued status attributed to elementary school teaching. Moreover, the opportunity for interrogating the role that homophobia and the policing of masculinities might have to play in male teachers' lives and the overall perception of men doing women's work is also lost (see Martino \& Frank, 2006). As Foster and Newman's (2005) research illustrates, what is needed in any attempt to address issues of male teacher recruitment is some interrogation of the "common sense belief that teaching children is not a suitable job for man [which] rests on a long history in which primary teaching has been seen as women's work, lacking status and lacking in intellectual challenge ...” (p. 347). Williams (1993), in fact, argues for the need to focus on developing a deeper understanding of what "keeps men out of female jobs," which requires, she claims, some interrogation of the social and economic forces that "sustain the exclusion of men" from women's work (p. 2). The question, hence, is one that relates to how men might be involved in teaching without an accompanying sense of fear and derision, which leads to and feeds into a recuperative masculinity politics committed to legitimating hegemonic masculinity. It is in this sense that the problematic gap between policy and research is symptomatic of the recuperative masculinity politics that sets up male teachers as victims of feminization.

\section{CONGLUSION}

In this article, my primary aim has been to illustrate the extent to which the role model discourse, within the context of moral concern about the call for more male teachers in elementary schools, is part of a broader cultural project of re-masculization. This has been manifested most significantly in terms of how male teachers and boys have been constituted on the basis of their essentialized gender attributes within the context of discussions about educational policy and popular media reports which reiterate the need for 
need for a more balanced teaching profession. Moreover, this article has been motivated by concerns about the absence of any interrogation of the continuing effects of the historical legacy of hegemonic masculinity, compulsory heterosexuality and homophobia that continue to underlie anxieties about the impact of feminization on male teachers and boys in elementary schools (Acker, 1995/96; Biklen, 1995; Blount, 2005; Heap \& Prentice, 1991; Lawn \& Grace, 1987; Prentice \& Theobald, 1991).

This article, therefore, provides a much needed perspective on the polemic of the male teacher as "a dying breed." It foregrounds the consequences of the failure to connect such concerns about male teachers to a broader social phenomenon regarding the anxiety about the status of masculinity in times of feminist backlash and how this, in turn, relates to the devaluation of what continues to be regarded as women's work. It is at this nexus of examining the impact and effects of hegemonic masculinity in relation to doing women's work, and, hence, engaging in what has been termed by King (1998) as "uncommon caring," that the male teacher debate has the potential to open up rather than to foreclose possibilities for raising critical questions about de-gendering and re-gendering of elementary school teaching. Such an approach resists the familiar tendency to resort to endorsing a form of re-masculinization committed to reinforcing a system of gender polarization that is grounded in a repudiation of the feminine (Butler, 1993). This provides a necessary platform or basis for advocating the need to bridge the gap between policy and research by incorporating literature that addresses the limitations imposed by regimes of normalization and enforced gender polarization in teachers' lives and how these impact on both their identities and pedagogical practices in schools.

\section{NOTES}

1. The term feminization, as it applies to elementary school teaching, relates to three interrelated phenomena: (1) the increasing number of female teachers relative to male teachers; (2) the cultural context or environment of school which is considered to be more "girl friendly"; (3) a backlash politics fuelled by global capitalism, which has had an impact on traditional patterns of employment, relationships, etc. (see Skelton, 2002). As Lingard and Douglas (1999) have argued, this has influenced significantly the perception of women in the workforce in terms of their perceived threat to male power.

2. The media reports included for analysis in this section of the article were selected after conducting an Internet search. They illuminate examples of the popular manifestations of the role model discourse vis-à-vis the call for more male elementary school teachers in the North American context. This is consistent with the analytic perspective on media backlash outlined by Faludi (1991) who claims that the media first introduced the backlash to a national audience in the United States and was instrumental in making it more palatable (p. 77). 


\section{REFERENCES}

Abbot, J. (1991). Accomplishing “a man's task": Rural women teachers, male culture, and the school inspectorate in the turn-of-the-century Ontario. In R. Heap \& A. Prentice (Eds.), Gender and education in Ontario (pp. 51-72). Toronto: Canadian Scholars' Press.

Acker, S. (1995/96). Gender and teachers' work. Review of Research in Education, 21, 99-162.

Acker, S. (Ed.). (1989). Teachers, gender and careers. New York: Falmer Press.

Allan, J. (1994). Anomaly as exemplar: The meanings of role-modeling for men elementary teachers. Dubuque, IA: Tri-College Department of Education, Loras College.

Altenbaugh, R. (Ed.). (1992). The teacher's voice: A social history of teaching in twentieth century America. London: Falmer Press.

Anderson, K., \& Accomando, C. (2002). "Real" boys? Manufacturing masculinity and erasing privilege in popular books on raising boys. Feminism E Psychology, 12(4), 491-516.

Ashley, M., \& Lee, J. (2003). Women teaching boys: Caring and working in the primary school. Stoke on Trent, UK: Trentham.

Barman, J. (1990). Birds of passage or early professionals? Teachers in late nineteenth century British Columbia. Historical Studies in Education, 2(1), 17-36.

Berrill, D., \& Martino, W. (2002). Pedophiles and deviants: Exploring issues of sexuality, masculinity and normalization in male teacher candidates' lives. In R. Kissen (Ed.), Waiting for Benjamin: Sexuality, curriculum and schooling (pp. 59-70). Lanham, MD: Rowman \& Littlefield.

Bhroimeil, U. (2006). "Sending gossoons to be made oul' mollies of": Rule 127 (b) and the feminization of teaching in Ireland. Irish Educational Studies, 25(1), 35-51.

Biklen, S. K. (1995). School work: Gender and the cultural construction of teaching. New York: Teachers College Press.

Binks, G. (2006, June 5). Don't stand so close to me. Retrieved, July 20, 2006, from http://www.cbc.ca/news/viewpoint/vp_binks/20060605.html

Bland, L., \& Doan, L. (1998). Sexology in culture: Labelling bodies and desires. Cambridge, UK: Polity.

Blount, J. (2000). Spinsters, bachelors, and other gender transgressors in school employment, 1850-1990. Review of Educational Research, 70(1), 83-101.

Blount, J. (2005). Fit to teach: Same-sex desire, gender, and school work in the twentieth century. Albany: State University of New York Press.

Bolch, M. (2006). Teacher man. Retrieved July 20, 2006, from http:// www.scholastic.com/administrator/mar06/articles.asp?article=MaleTeachers

Bradley, H. (1993). Across the great divide: The entry of men into "women's jobs." In C. Williams (Ed.), Doing “women's work": Men in nontraditional occupations (pp. 10-27). Newbury Park, CA: Sage.

Britzman, D. (1993). Beyond rolling models: Gender and multicultural education. In S. K. Biklen \& D. Pollard (Eds.), Gender and education (pp. 25-42). Chicago: University of Chicago Press.

Britzman, D. (1998). Lost subjects, contested objects. New York: State University of New York Press.

Burn, E. (2001). Do boys need male primary teachers as positive role models? Paper presented at the British Research Association Annual Conference, University of Leeds, September 13-15.

Butler, J. (1993). Bodies that matter: On the discursive limits of sex. New York: Routledge.

Carrington, B. (2002). A quintessentially feminine domain? Student teachers' constructions of primary teaching as a career. Educational Studies, 28(3), 287-303. 
Cativo, F. (2006). Some pupils find men at head of the class. Retrieved July 20, 2006, from http://www.courant.com/news/local/hc-whdmale0609.artjun09,0,47

Cavanagh, S. (2005a). Female teacher gender and sexuality in twentieth century Ontario Canada. In R. Coulter \& H. Harper (Eds.), History is hers: Women educators in twentieth century Ontario (pp. 111-136). Calgary, AB: Detselig Enterprises.

Cavanagh, S. (2005b). Nervous narratives: Female teacher maladies in the twentieth century. In R. Coulter \& H. Harper (Eds.), History is hers: Women educators in twentieth century Ontario (pp. 193-210). Calgary, AB: Detselig Enterprises.

Cavanagh, S. (2006) Spinsters, schoolmarms, and queers: Female teacher gender and sexuality in medicine and psychoanalytic theory and history. Discourse, 27(4), 421-440.

Clifford, G. J. (1989). Man/women/teacher: Gender, family, and career in American educational history. In D. Warren (Ed.), American teachers: Histories of a profession at work (pp. 293-343). New York: Macmillan.

Cloer, A. (2006). Male classroom teachers. Retrieved July 20, 2006, from http:// newteachersupport.suite101.com/article.cfm/TheMaleClassroomTeacher

Connell, B. (1995). Masculinities. Sydney, Australia: Allen \& Unwin.

Connell, R. W. (1996). Teaching the boys: New research on masculinity, and gender strategies for schools. Teachers College Record, 98(2), 206-235.

Cortina, R., \& San Roman, S. (Eds.). (2006). Women and teaching: Global perspectives on the feminization of a profession. New York: Palgrave.

Coulter, R., \& Harper, H. (Eds.). (2005). History is hers: Women educators in twentieth century Ontario. Calgary, AB: Detselig Enterprises.

Coulter, R., \& McNay, M. (1993). Exploring men's experiences as elementary school teachers. Canadian Journal of Education, 18(4), 398-413.

Danylewycz, M., Light, B., \& Prentice, A. (1983). The evolution of the sexual division of labour in teaching: A nineteenth century Ontario and Quebec case study. Histoire sociale/ Social History, 16, 81-109.

du Toit, K. (2003). The pussification of the Western male. Retrieved July 20, 2006, from http://www.theothersidefkim.com/index.php/essays/41/

Elementary Teachers' Federation of Ontario. (2003). EFTO encourages males in elementary. EFTO Voice, 5(3), 20.

Elementary Teachers' Federation of Ontario. (2006, May 3). Is the male teacher becoming extinct? Symposium, Toronto, ON.

Faderman, L. (1998). Surpassing the love of men: Romantic friendship and love between women from the Renaissance to the present. New York: Quill.

Faludi, S. (1991). Backlash: The undeclared war against women. London: Vintage.

Foster, T., \& Newman, E. (2005). Just a knock back? Identity bruising on the route to becoming a male primary school teacher. Teachers and Teaching: Theory and Practice, 11(4), 341-358.

Francis, B., \& Skelton, C. (2001). Men teachers and the construction of heterosexual masculinity in the classroom. Sex Education, 1(1), 9-21.

Frank, B. (1987). Hegemonic heterosexual masculinity. Studies in Political Economy, 24, 159-170.

Gilles, C. (2005, October 31). He's come undone. McLean's Magazine, pp. 28-34.

Gold, D., \& Reis, M. (1982). Male teacher effects on young children: A theoretical and empirical consideration. Sex Roles, 8, 493-513.

Green, C. (1991). Review: The "boy problem" and the "woman question." American Quarterly, 43(4), 661-667.

Halberstam, J. (1998). Female masculinity. Durham, NC: Duke University Press.

Harding, J. (1998). Sex acts: Practices of femininity and masculinity. London: Sage.

Heap, R., \& Prentice, A. (Eds.). (1991). Gender and education in Ontario. Toronto: Canadian Scholars' Press. 
Higgins, L. (2002). Wanted more male teachers. Detroit Free Press. Retrieved July 20, 2006, from http://www.detnews.com/2002/schools/0212/30/a04-47848.htm

Hoff Sommers, C. (2000). The war against boys. The Atlantic Monthly, 285(5), $59-74$

House of Representatives Standing Committee on Education and Training. (2002). Boys' education: Getting it right. Canberra: Commonwealth Government of Australia.

Ingersoll, R. (2001). Teacher turnover, teacher shortages, and the organization of schools. Seattle: Centre for the Study of Teaching and Policy, University of Washington.

Kendall, C., \& Martino, W. (2006). Gendered outcasts and sexual outlaws. New York: Haworth Press.

Kimmel, M. (1993). Foreword. In C. Williams (Ed.), Doing "women's work": Men in nontraditional occupations (pp. ix-x). Newbury Park, CA: Sage.

King, J. (1998). Uncommon caring: Learning from men who teach young children. New York: Teachers College Press.

King, J. (2004). The (im) possibility of gay teachers for young children. Theory Into Practice, 43(2), 122-127.

Lawn, M., \& Grace, G. (Eds.). (1987). Teachers: The culture and politics of work. London: Falmer Press.

Lingard, B. (2003). Where to in gender theorising and policy after recuperative masculinity politics? International Journal of Inclusive Education, 7(1), 33-56.

Lingard, B., \& Douglas, P. (1999). Men engaging feminisms: Profeminism, backlashes and schooling. Buckingham, UK: Open University Press.

MacDonald, J. (2003, July 15). Too few good men. Retrieved July 20, 2006, from http://www.csmonitor.com/2003/0715/p13s01-lecl.html

Mahony, P., Hextall, I., \& Menter, I. (2004). Threshold assessment and performance management: Modernizing or masculinizing teaching in England. Gender and Education, 16(2), 132-149.

Martino, W. (2004). "The boy problem": Boys, schooling and masculinities. In R. Transit (Ed.), Disciplining the child via the discourse of the professions (pp. 19-33). Springfield, IL: Charles C. Thomas.

Martino, W. (2006). The "right" way to educate boys: Interrogating the politics of boys' education in Australia. In C. Skelton, B. Francis, \& L. Smulyan (Eds.), The Sage handbook of gender and education (pp. 350-364). London: Sage.

Martino, W. (2008). Beyond male role models: Interrogating the role of male teachers in boys' education. In W. Martino, M. Kehler, \& M. Weaver-Hightower (Eds.), Boys' education: Beyond the backlash. New York: Routledge.

Martino, W., \& Berrill, D. (2003). Boys, schooling and masculinities: Interrogating the "right" way to educate boys. Education Review, 55(2), 99-117.

Martino, W., \& Frank, B. W. (2006). The tyranny of surveillance: Male teachers and the policing of masculinities in a single sex school. Gender $\mathcal{E}$ Education, 18(1), $17-33$.

Martino, W., \& Kehler, M. (2006). Male teachers and the "boy problem": An issue of recuperative masculinity politics. McGill Journal of Education, 41(2), $1-19$.

Martino, W., Mills, M., \& Lingard, B. (2004). Issues in boys' education: A question of teacher threshold knowledge. Gender and Education, 16(4), 435-454.

Miller, J. (1996). School for women. London: Virago.

Mills, M. (2003). Shaping the boys' agenda: The backlash blockbusters. International Journal of Inclusive Education, 7(1), 57-73.

Mills, M., Martino, W., \& Lingard, B. (2004). Attracting, recruiting and retaining male teachers: Policy issues in the male teacher debate. British Journal of the Sociology of Education, 25(3), 355-369. 
Mills, M., Martino, W., \& Lingard, B. (2007). Getting boys' education "right": The Australian Government's Parliamentary Inquiry Report as an exemplary instance of recuperative masculinity politics. British Journal of Sociology of Education, 28(1), $5-21$.

Mitchell, A. (2004, January 17). "Goodbye Mr Chips." Globe and Mail.

National Education Association (NEA). (2004, April 28). Are male teachers on the road to extinction? Retrieved July 20, 2006, from http://www.nea.org/ newsreleases/2004/nr040428.html

Ontario College of Teachers. (2004). Narrowing the gender gap: Attracting men to teaching. Retrieved July 1, 2006, from http://www.oct.ca/publications/ documents.aspx?lang=en-CA

Oram, A. (1983). Serving two masters? The introduction of a marriage bar in teaching in the 1920s. In London Feminist History Group (Ed.), The sexual dynamics of history (pp. 134-138). London: Pluto.

Oram, A. (1989). A master should not serve under a mistress: Women and men teachers 1900-1970. In S. Acker (Ed.), Teachers, gender and careers (pp. 21-34). Lewes, UK: Falmer Press.

Orlando, L. (2005, September 8). Schools working hard to attract more male teachers. Retrieved July 20, 2006, from http://www.buzzle.com/editorials/8-8-200574484.asp

Pepperell, S., \& Smedley, S. (1998). Call for more men in primary teaching: Problematizing the issues. International Journal of Inclusive Education, 2(4), 341-357.

Petersen, A. (1998). Unmasking the masculine: Men and identity in a sceptical age. London: Sage.

Prentice, A., \& Theobald, M. (Eds.). (1991). Women who taught: Perspectives on the history of women and teaching. Toronto: University of Toronto Press.

Renold, E. (2003). "If you don't kiss me, you're dumped": Boys, boyfriends and heterosexualised masculinities in the primary school. Educational Review, 55(2), $179-194$.

Roulston, K., \& Mills, M. (2000). Male teachers in feminised teaching areas: Marching to the men's movement drums. Oxford Review of Education, 26(1), 221-237.

Runevitch, J. (2003, November 26). Male teachers needed in elementary schools. Retrieved July 20, 2006, from http://www.wndu.com/news/malementors/ malementors_3854.php?

Rury, M. W. (1989). Who became teachers? The social characteristics of teachers in American history. In D. Warren (Ed.), American teachers: Histories of a profession at work (pp. 9-48). New York: Macmillan.

Sargent, P. (2005). The gendering of men in early childhood education. Sex Roles, 52(3-4), 251-259.

Sears, J. (1999). Teaching queerly: Some elementary propositions. In W. Letts \& J. Sears (Eds.), Queering elementary education: Advancing the dialogue about sexualities and schooling (pp. 3-14). Lanham, MD: Rowman \& Littlefield.

Sexton, P. (1969). The feminized male: Classrooms, white collars, E the decline of manliness. New York: Random House.

Skelton, C. (2001). Schooling the boys: Masculinities and primary education. Buckingham, UK: Open University Press.

Skelton, C. (2002). The feminisation of schooling or re-masculinising primary education? International Studies in Sociology of Education, 12(1), 77-96.

Skelton, C. (2003). Male primary teachers and perceptions of masculinity. Education Review, 55(2), 195-210.

Smedley, S. (2006). Listening to men student primary school teachers: Some thoughts on pedagogy. Changing English, 13(1), 125-135. 
Sugg, R. (1978). Motherteacher: The feminization of American education. Charlottesville: University of Virginia Press.

Sykes, H. (2004). Genderqueer: Transphobia and homophobia in schools. Orbit, 34(1), 21.

Talburt, S., \& Steinberg, S. (Eds.). (2000). Thinking queer: Sexuality, culture and education. New York: Peter Lang.

Titus, J. (2004). Boy trouble: Rhetorical framing of boys' underachievement. Discourse, 25(2), 145-169.

Tyack, D. B., \& Hansot, E. (1982). Managers of virtue: Public school leadership in America, 1820-1890. New York: Basic Books.

Vincinus, M. (1985). Independent women: Work and community for single women, 18501920. Chicago: University of Chicago Press.

Williams, C. (1993). Doing “women's work": Men in nontraditional occupations. Newbury Park, CA: Sage. 